\title{
Mobile Artisanal Cheese Vending in Small Street Markets of Gran Canaria
}

\section{Maria del Pino Sánchez ${ }^{1}$, Dácil Lugo ${ }^{1}$, Rafael Millán ${ }^{1}$, Abel Verdú ${ }^{1}$, António Raposo ${ }^{*_{2}}$, Esther Sanjuán ${ }^{1}$ and Conrado Carrascosa $\mathbf{a}^{1}$}

${ }^{1}$ Department of Animal Pathology and Production, Bromatology and Food Technology, Faculty of Veterinary, Universidad de Las Palmas de Gran Canaria, Trasmontaña s/n, 35413 Arucas, Spain

${ }^{2}$ Centro de Investigação Interdisciplinar Egas Moniz, CiiEM, Instituto Superior de Ciências da Saúde Egas Moniz, ISCSEM, Quinta da Granja, Monte de Caparica, 2829-511 Caparica, Portugal

\section{Abstract}

This survey-based study evaluates the effect of three factors (market location, kind of stall facilities and presence of intermediaries) on the hygienic-sanitary quality of markets, which could condition the food risk of the artisanal cheeses sold in them. As street vending in the Canaries archipelago is important tocommercialise traditional reference products, thisstudy compares the hygienic-sanitary conditions of stalls in several street markets on the Gran CanariaIsland by taking artisanal cheese as a reference product. The results show that the markets in coastal areas obtain a higher food sellers score than those in inland areas. Presence of permanent stalls allows the hygienic-sanitary criteria set out by law on street sales to be better applied than markets with temporary stalls. The former obtain much higher scores than the latter. Finally, presence of intermediaries made the survey scores drastically lower, but theywere higher when producers ranstalls. Facilitating the staff in this sector access to specialised training is fundamental. This is the main problem faced in such businesses, followed by asking competent authorities to collaborate more to ensure that current legislation is met, and to protect and improve traditional sales as their importance in society and today's economy in many regions is vital.

\section{Introduction}

Given its privileged geographical location, the Canaries archipelago is visited by 12 million tourists each year who demanda seriesof products, which include traditional artisanal foodstuffs thatgenuinely represent the culture of the Canaries. Some have obtained an Appellation of Origin (AoO) from the EU. Street markets are a traditional way of selling local products on the Canary Islands. Street vending is defined in Spanish Law 7/1996[1] as sales made habitually occasionally, periodically or continuouslyby traders outside a permanent business setting,and on outskirts or in duly authorised places on commercial stalls that can be dismantled or transported, including retail sale lorries.Such sales can only be carried out in permanent, occasional or periodical markets, and in street markets, for seasonal products.According to McHardy et al. [2], street vendors are one of the major components of unofficial economy. Because street vending has proved to be a good source of income thatrequires little capital investment, it continues to increase [3]. The economic crisis that affects global economy is making informal economy more important as millions are being downsized from permanent positions [4]. At least once a weekin almost every town, producers from all around the island sells their products on different stalls located in street markets. Street vendors conveniently set up their stalls in residential areas, near workplaces or on routesused by thousands of commuters, and they provide a source of inexpensive, convenient and comparatively nutritious food 5]. European requirements for movable and/or temporary premises (such as market stalls) are set out in Chapter III of AnnexII in Regulation 852/2004 [6]. The Spanish ones are found in Chapter IV of Law 7/1996 and in Royal Decree 199/2010 [7].Anyone who intends to undertake this activity must comply with the specifications described in them to meet food safety objectives. Studies conducted to assess the quality of different street foods in several countries have shown that these foods are positive vectors of foodborne illnesses [8-11]. Thus a hygienic-sanitary control of the stalls where such foodstuffs are sold is fundamental.

Among the wide range of foodstuffs that we encounter in street markets of Gran Canaria (spicy sausages, black puddings, honey, olives, bread, etc.), we took the artisanal cheeses of Gran Canariaas

\section{Publication History:}

Received: August 25, 2014

Accepted: November 20, 2015

Published: November 23, 2015

\section{Keywords:}

Street vending, Food safety, Gran Canaria, Artisanal cheese the reference product to conduct the present research given their prestige and acceptance by the Canary society. It is estimated that artisanal cheese production represents $78 \%$ of the total cheese production on the Canary Islands (17,000 tonnes/year), which came to 13,260 tonnes in 2008 [12]. This kind of cheese is produced all over the island, where there were some 176 dairies in 2010 according to the Regional Ministry of Agriculture, Cattle, Fishing and Waters of the Canaries Government. The production of artisanal dairies is limited; whichhave had to make marked changes to adapt to Council Directive 92/46/EEC [13]. These changes have meant the closure of some obsolete dairies, but have encouraged most artisanal dairies to modernise to adapt to today's hygienic-sanitary requirements [14].

These cheeses have been widely studied by various authors as far as their organoleptic characteristics and hygienic-sanitary conditions during manufacturing processes are concerned [15-18]. We believe it is important to evaluate the characteristics of the traditional markets where these famous foodstuffs are sold because they are often a way to attract many native island consumers, tourists and visitors, who take advantage of this traditional form of selling. For all these reasons, we believe that it is essential to set the following objectives for the present study:

1. Comparing the hygienic-sanitary conditions of street vending stalls by taking the artisanal cheeses of Gran Canariaas reference product.

2. Evaluating the effect of three factors (market location, kind of stall facilities and presence of intermediaries) on the hygienic-

"Corresponding Author: Dr. António Raposo, Centro de Investigação Interdisciplinar Egas Moniz, CiiEM, Instituto Superior de Ciências da Saúde Egas Moniz, ISCSEM, Quinta da Granja, Monte de Caparica, 2829-511 Caparica, Portugal; E-mail: araposo@egasmoniz.edu.pt

Citation: Sánchez MP, Lugo D, Millán R, Verdú A, Raposo A, et al. (2015) Mobile Artisanal Cheese Vending in Small Street Markets of Gran Canaria. Int J Clin Nutr Diet 1: 101. doi: http://dx.doi.org/10.15344/ijcnd/2015/101

Copyright: (C) 2015 Sánchez et al. This is an open-access article distributed under the terms of the Creative Commons Attribution License, which permits unrestricted use, distribution, and reproduction in any medium, provided the original author and source are credited. 
Citation: Sánchez MP, Lugo D, Millán R, Verdú A, Raposo A, et al. (2015) Mobile Artisanal Cheese Vending in Small Street Markets of Gran Canaria. Int J Clin Nutr Diet 1: 101. doi: http://dx.doi.org/10.15344/ijcnd/2015/101

Page 2 of 5

sanitary quality of markets,which could condition the food risk of the artisanal cheeses sold in them

\section{Material and Methods}

\section{Street markets}

Given the importance of this typeof business, seven historical markets were visited, located in different towns on the Gran CanariaIsland andidentified in Figure 1, to evaluate the hygienicsanitary conditions of the stalls in them. Of all the street markets on the island, we selected these seven for their large-sized location and its historic importance. All seven fulfilled these characteristics: their legislative basis lay in the bylaws and regulations set out by Town Councils; foodstuffs are sold in designated areas, either on the street or in the owner's facilities.

For this research work, the following factors were considered: "kind of facilities", which could be permanent or temporary (removable) stalls; located in a coastal area or in an inland area on the island.These factors were assessed to see if they possibly influenced the results of Hygiene Assessment System (HAS) surveys. We also made a note of whether the products on all the stalls were sold directly by producers or through intermediaries to see if this factor influenced the HAS results. The characteristics of each street market are provided in Table 1.

\begin{tabular}{|l|l|l|l|l|}
\hline Street Market & Facilities & Area & \multicolumn{2}{|l|}{$\begin{array}{l}\text { Number of stalls } \\
\text { (Artisanal Cheeses Sold) }\end{array}$} \\
\cline { 3 - 5 } & & & $\begin{array}{l}\text { Has } \\
\text { Survey }\end{array}$ & Total Stalls \\
\hline $\begin{array}{l}\text { Granja del } \\
\text { Cabildo (Arucas) }\end{array}$ & Permanent & Inland & 1 & 7 \\
\hline $\begin{array}{l}\text { Maspalomas (S. } \\
\text { Bartolomé) }\end{array}$ & Permanent & Coastal & 7 & 7 \\
\hline Mogán & Temporary & Coastal & 1 & 1 \\
\hline San Mateo & Permanent & Inland & 8 & 11 \\
\hline Santa Brígida & Permanent & Inland & 1 & 1 \\
\hline Teror & Temporary & Inland & 12 & 14 \\
\hline Vecindario & Permanent & Inland & 10 & 10 \\
\hline Total & - & - & 40 & 51 \\
\hline
\end{tabular}

Table 1: Characteristics of the street markets assessed in this research work. The number of stalls that sold artisanal cheeses and accepted to participate in the HAS survey is shown (for all the market stalls).

\section{HAS surveys}

In order to assess the conditions of markets to adapt to the expected hygienic-sanitary requirements, a HAS survey was done in which each question gave a score according to the degree of fulfilment of the stalls on a predetermined scale. To conduct this research, aHAS survey was conducted to evaluate if the hygienic-sanitary conditions for mobile vending (Millán et al.,[19]adapted to particular street vending conditions).

The scores of each generic heading of the HAS survey and its respectiveitems to be evaluated were obtained according to: current community and domestic regulations on mobile vending (previously cited); technical-sanitary cheese regulations [20]; current scientific knowledge on food hygiene and technology; one's own professional experience while visiting markets. A higher score was given to the handling operations and facilities that entailed greater risk. The four generic headings that were taken into account, and their respectiveitems, were:
1. Food sellers (100 points): food handlers training; wearing specific clothes, hair cap and gloves, but no jewellery; hygienicsanitary conditions of staff and product handling.

2. Technical-sanitary conditions of the food display stands in the market (50 points): hygienic-sanitary conditions; stock rotation; LDDD plan

3. Equipment (50 points): hygienic-sanitary conditions; presence of a clean washable cutting board; a specific knife per food type; stainless steel instruments

4. Hygienic-sanitary conditions of cheese (100 points): proximity toother foods; correct conservation; clean correct packaging; protection from sunlight; cheese labelling is in accordance with specific legislation and traceability

The HAS survey includes 300 points, and these reference values for scores were set: unacceptable $(<40 \%)$; acceptable $(40-70 \%)$ and satisfactory $(>70 \%)$. These values were contemplated after bearing in mind the results obtained in other works $[12,19,21]$ and were also determined according to experience acquired. All the results foreach street market stall were saved in a database to be subsequently analysed. Here the results were grouped into markets to compare them with each other and to detect differences in evaluations, if any, which could be influenced by the particular characteristics of each one.

\section{Statistical analysis}

The objective here was to evaluate the effects of the three study factors (market location, kind of stall facilities and presence of intermediaries) on the hygienic-sanitary quality of cheeses in street vending markets. For this purpose, a cross-sectional study was designed, which included 40 stalls locatedin the seven street vending markets selectedfor the present research work.

For all the considered generic headings and factors in the HAS surveys, total scores were summarised according tomedians and interquartile ranges (IQR). Medians were compared using the Wilcoxon test for independent data. Statistical significance was set at $\mathrm{p}<.05$. Data were analysed with the R-package, version 3.1.0 ( $\mathrm{R}$ Development Core Team, 2014).

\section{Results and Discussion}

The results of the statistical analysis (Table 2) revealed that if the market where cheeses were sold was located in a coastal area, or not, significantly influenced $(\mathrm{p}<0.009)$ the results obtained in the HAS survey on food sellers. The mean score obtained for coastal market stalls was better than those located in land (77.5 vs. 63.1$)$. In any case, the obtained scores were low, and many shortcomings were found in both locations. This means that current legislation is not being metand can pose risks for the consumers who buy these foodstuffs. Observing personal hygiene is vital for any food establishment. Anyone handling food who observes other forms of higiene, and not personal hygiene, will definitely contaminate food. The fact that street market employees have failed to comply with regulations has been reported in other studies [22-27]. The differences found in both locations might be due to coastal markets having better conditions as tourists are present on almost a daily basis, not onlyfrom guided visits, which normally visit inland markets, but also from cruises and tourist residential areas, which generally abound in areas near the coast. More local citizens and fewer tourists tend to visit inland markets as they are further away from coastal tourist areas. This situation means that food sellers in 
Citation: Sánchez MP, Lugo D, Millán R, Verdú A, Raposo A, et al. (2015) Mobile Artisanal Cheese Vending in Small Street Markets of Gran Canaria. Int J Clin Nutr Diet 1: 101. doi: http://dx.doi.org/10.15344/ijcnd/2015/101

Page 3 of 5

\begin{tabular}{|c|c|c|c|c|c|c|c|c|c|}
\hline & \multicolumn{3}{|l|}{ Coastal } & \multicolumn{3}{|l|}{ Facilities } & \multicolumn{3}{|l|}{ Inland } \\
\hline & $\begin{array}{l}\text { No } \\
\mathrm{N}=32\end{array}$ & $\begin{array}{l}\text { Yes } \\
\mathrm{N}=8\end{array}$ & $\mathrm{P}$ & $\begin{array}{l}\text { No } \\
\mathrm{N}=13\end{array}$ & $\begin{array}{l}\text { Yes } \\
\mathrm{N}=27\end{array}$ & $\mathrm{P}$ & $\begin{array}{l}\text { No } \\
\mathrm{N}=18\end{array}$ & $\begin{array}{l}\text { Yes } \\
\mathrm{N}=22\end{array}$ & $\mathrm{P}$ \\
\hline Foodsellers & $\begin{array}{l}63.1 \\
(57 ; 73)\end{array}$ & $\begin{array}{l}77.5 \\
(77 ; 78)\end{array}$ & .009 & $\begin{array}{l}58.2 \\
(56 ; 65)\end{array}$ & $\begin{array}{l}75.2 \\
(62 ; 78)\end{array}$ & .005 & $\begin{array}{l}77.5 \\
(73 ; 78)\end{array}$ & $\begin{array}{l}58.2 \\
(56 ; 66)\end{array}$ & $<.001$ \\
\hline $\begin{array}{l}\text { T-S condit. of } \\
\text { display cases }\end{array}$ & $\begin{array}{l}0 \\
(0 ; 42)\end{array}$ & $0^{*}$ & .060 & $0^{*}$ & $\begin{array}{l}0 \\
(0 ; 42)\end{array}$ & .009 & $0^{*}$ & $\begin{array}{l}0 \\
(0 ; 42)\end{array}$ & .245 \\
\hline Equipment & $\begin{array}{l}25.0 \\
(15 ; 40)\end{array}$ & $\begin{array}{l}22.5 \\
(20: 22)\end{array}$ & .599 & $\begin{array}{l}16.0 \\
(15 ; 20)\end{array}$ & $\begin{array}{l}30.0 \\
(21 ; 40)\end{array}$ & .002 & $\begin{array}{l}22.5 \\
(17 ; 29)\end{array}$ & $\begin{array}{l}23.0 \\
(15 ; 39)\end{array}$ & .643 \\
\hline $\begin{array}{l}\text { H-S condit. of } \\
\text { cheeses }\end{array}$ & $\begin{array}{l}63.0 \\
(32 ; 80)\end{array}$ & $\begin{array}{l}58.0 \\
(57.7 ; 62)\end{array}$ & .932 & $\begin{array}{l}31.0 \\
(29 ; 32)\end{array}$ & $\begin{array}{l}70.0 \\
(58 ; 83)\end{array}$ & $<.001$ & $\begin{array}{l}60.0 \\
(57 ; 70)\end{array}$ & $\begin{array}{l}34.5 \\
(31 ; 80)\end{array}$ & .437 \\
\hline
\end{tabular}

Table 2: Medians (IQR) for the scores according to the considered generic headings and factors.

$\left({ }^{*}\right)$ Allvalues are zeros

coastal markets are more concerned about that food sellers in coastal markets are more concerned about looking after certain details, which does not occur in inland markets as food sellers are in contact with regularlocal buyers, so they pay less attention to certain aspects. The implementation of a comprehensive, mandatory vending education programme for sellers that focuses exclusively on mobile vending issues could improve the current situation [28].

Likewise, the scores obtained in all the generic headings considered in the survey (food sellers, technical-sanitary conditions of display cases, equipment and hygienic-sanitary conditions of cheeses) indicated significant differences depending on whether the stall facilities in markets were permanent or temporary: the evaluation of the HAS survey results was clearly better for permanent market stall facilities. This is because it is easier to meet the requirements set out in various regulations on permanent market stalls since they are better prepared to house them, they are easier to clean and disinfect, and it is easier to install temperature control equipment and devices. A temporary stall were poorly constructed and usually located outdoors, and not always with a roof or cover, and in high pedestrian traffic areas like squares or avenues. This often implies problems when making available a supply of running water or electricity. So consequently they obtained lower scores for food conservation conditions, and cleanliness of stalls and the staff working on them. Maintaining food hygiene is difficult in practice in street settings where resources are scarce and surroundings present poor environmental and sanitary standards [29]. Not having enough water means not meeting hygiene and sanitary practices. All these findings match the conclusions drawn in similar works, in which most of these vending sites also lacked basic infrastructure and services, such as running water and waste disposal facilities, hand and dishwashing water are usually insufficient and often reused, and sometimes even without soap. Waste water is thrown into the street and rubbish isoften disposed of in the vicinity of the stall. All this leads to lower survey scores [22,24,27,30]. According to Lues et al. [3], only in exceptional cases do these stalls have adequate refrigeration facilities, without which a health risk is posed, especially in warmer seasons when food is on display for long periods of time.

Lack of intermediaries to commercialise this food product on stalls had a marked influence ( $\mathrm{p}<0.001$ ), but only on the assessment of market food sellers (77.5 vs. 58.2). This is mainly because producers tend to possess more knowledge about legislation on the hygienicsanitary conditions of their production and sales of foodstuffs, which intermediaries (employees or intermediaries' customers) do not generally possess. Producers who sell their own food stuffs tend to take more care of the image of whatever surrounds them, and look after the tiniest details. This is something that intermediaries would probably neglect as they have no reason to consider them, except for making money on the sales of these products. A similar study by Choudhury et al. [31] also concluded that there was a high degree of association among procurement practices with vendor type, ownership status and average income. Given the significant importance of the street-food trade, some measures should be taken, such as offering qualification courses to street-food sellers, employing the HACCP system as a strategy to prevent contamination, adopting regulatory policies, among others [32]. Accordingly, Choudhury et al, [33] concluded that food vendors knowledge increased after training events, and the overall performance rating of sellers who fully adopted good hygiene practices ranged from $37.5 \%$ to $50.8 \%$ during the post-training period.

Thus the influence that the three classification factors considered herein had onfood sellers was more significant. Presence of intermediaries had a very marked effect $(\mathrm{p}<0.001)$, followed by presence of permanent facilities $(\mathrm{p}<0.005)$ and location in a coastal area $(p<0.009)$. Nevertheless, the only classification factor to have influenced the score obtained for the other generic headings in the HAS survey (technical-sanitary conditions of display cases, equipment and hygienic-sanitary conditions of cheeses) was if stalls were permanent or not in the markets under study, with significance at $\mathrm{p}<0.009, \mathrm{p}<0,002$ and $\mathrm{p}<0.001$, respectively. According to the research results of Sun et al., [34], street food vendor's knowledge of food safety and hygienewas limited given poor hygiene practices, as reflected by the food sold; this possibly causes foodborne illness problems that affectthe image of tourism. Forbidding sales of street food will not solve the food safety problem. In addition, controlling the street food sold is challenging because of the difficulty encountered by food vendorsin applying sanitary regulations, the large number of food vendors and their mobility [35]. Strategies to address the assessment challenges that emerged in the research of Lucan et al. [36] may help make mobile vendor assessments become more routine-like in food-environment research. There is also a need to generate food and personal hygiene, and to ensure an effective system of regular hygienic-sanitary examinations with vendors and regular sample collections of the foodstuffs sold to customers [37]. Food vendors are recommended to maintain standard environmental and personal hygiene while preparing, packaging or serving food products to consumers [38]. Proietti et al. [39] proposed specific points of attention for street food preparation and sales based on related hazard-tailored actions. Street food sales should become a major target of food security and food safety policies, and should be addressed comprehensively and innovatively, by exploiting and integrating the growing knowledge on toxicological risk factors in developing countries in order to strike an optimal balance between risks and social and nutrition benefits. 
Citation: Sánchez MP, Lugo D, Millán R, Verdú A, Raposo A, et al. (2015) Mobile Artisanal Cheese Vending in Small Street Markets of Gran Canaria. Int J Clin Nutr Diet 1: 101. doi: http://dx.doi.org/10.15344/ijcnd/2015/101

Page 4 of 5

\section{Conclusion}

According to the results obtained on the influence of the three study factors, we conclude that market location significantly affects the score obtained in HAS surveys for food sellers, and this score is higher in coastal areas than in inland areas. As other research works have indicated for similar street markets, the scores obtained for food sellers are generally low, and shortcomings were detected in the hygiene of the staff running stalls. Therefore, designing specific training programmes to cover the particular requirements in this sector is vital.

Regarding facilities types, better results were obtained in the hygienic-sanitary quality survey for permanent market stall facilities. This is because they have better access to running water, so they can wash hands and tools, and they generally possess better equipment as they have access to power points, and designated waste disposal areas. A series of handicaps was found for temporary market stalls as they have difficult access to running water, electricity and to places to dispose waste, which all imply worse scores.

For presence of intermediaries, evidentlypreparation, knowledge and complying with legal regulations improve when the producers themselves distribute their own cheeses on stalls, and more hygienicsanitary errors are made when intermediaries run them.

Given the importance of street vending, especially for traditionallocal foodstuffs like cheese, more training activities for the staff of such businesses are required since this is precisely where the greater significance of the three factors studied herein was observed. It is also essential for the competent authorities to ensure that the current legislation in force is being met in order to avoid possible consumer health problems when hygienic-sanitary shortcomings come into play. This would help make this very important activity for local economy last; many families in countries worldwide depend on it, especially as far as local traditional products are concerned, because they use these markets as a showroom to present their foodstuffs.

\section{Competing Interests}

The author declare that she has no competing interests.

\section{References}

1. Law $7 / 1996$, de 15 de enero, de ordenación del comercio minorista.

2. Reid DM, Fram EH, Guotai C (2010) A Study of Chinese Street Vendors: How They Operate. Journal of Asia-Pacific Business 11: 244-257.

3. Lues JFR, Rasephei MR, Venter P, Theron MM (2006) Assessing food safety and associated food handling practices in street food vending. International Journal of Environmental Health Research 16: 319-328.

4. Barta P (2009) Global economics: The rise of the underground. Wall Street Journal, p. 1

5. Food and Agriculture Organisation, FAO (1997) Street food: small entrepreneurs, big business.

6. Regulation (EC) No 852/2004 of the European Parliament and of the Council of 29 April 2004 on the hygiene of foodstuffs. Official Journal L 139, $30 / 4 / 2004$, p. $1-54$

7. Royal Decree $199 / 2010$, de 26 de febrero, por el que se regula el ejercicio de la venta ambulante o no sedentaria.

8. Freese E, Romero-Abal ME, Solomons NW, Gross R (1998) The microbiological safety of typical Guatemalan foods from street vendors, low-income homes and hotels. International Journal of Food Science and Nutrition 49: 27-38.

9. Mosupye FM, von Holy A (1999) Microbiological quality and safety of readyto-eat street-vended foods in Johannesburg, South Africa. J Food Prot 62: 1278-1284.
10. Umoh VJ, Odob MB (1999) Safety and quality evaluation of street foods sold in Zaria, Nigeria. Food Control 10: 9-14.

11. Omemu AM, Edema MO, Bankole MO (2005) Bacteriological assessment of street vended ready to eat (RTE) vegetables and prepacked salad in Nigeria. Nigerian Journal of Microbiology 19: 497-504.

12. Carrascosa C (2010) Hygienic-sanitary evaluation of Canaries industrial and artisanal dairy establishments. Doctoral Thesis. University of Las Palmas of Gran Canaria (ULPGC). Spain.

13. Council Directive 92/46/EEC of 16 June 1992 laying down the health rules for the production and placing on the market of raw milk, heat-treated milk and milk-based products. Official Journal L 268, 14/09/1992 P. $0001-0032$.

14. Fresno M (2000) Application of sanitary european policy on the canarian farm cheese. Proc. 7th International Conference on Goats, Poitiers (Francia).

15. Millán R, Sanjuán E, Rodríguez E, Penedo JC, Castelo M (1990) Caracterización de quesos genuinos Canarios. Canarias Agraria y Pesquera, número: 10 Julio/Agosto/Septiembre.

16. Castelo M, Muñoz M, Cardona A, Salazar A, Sanjuán E, et al. (1992) Estudio de algunas poblaciones microbianas en cinco grupos de quesos canarios. Alimentaria. Marzo 45-47.

17. Castelo M (1995) Componentes físico-químicos, microbiológicos y evaluación sensorial de quesos canarios: Estudio individual y comparado. Doctoral Thesis. University of Las Palmas of Gran Canaria (ULPGC). Spain.

18. Sanjuán E, Millán R, Saavedra P, Carmona MA, Gómez R, et al. (2002) Influence of animal and vegetable rennet on the physicochemical characteristics of Los Pedroches cheese during ripening. Food Chemistry 78: 281-289.

19. Millán R, Pérez E, Sanjuán E, Carrascosa C, Mauricio C (2009) Evaluación higiénico-sanitaria en Centros de un Campus Universitario. O Médico Veterinário, volume jul-ago-sept 11-18.

20. Royal Decree $1113 / 2006$, de 29 de septiembre, por el que se aprueban las normas de calidad para quesos y quesos fundidos.

21. Pérez E (2012) Aportaciones al sistema de autocontrol en microestablecimeintos alimentarios de restauración colectiva. Doctoral Thesis. University of Las Palmas of Gran Canaria (ULPGC). Spain.

22. Muinde OK, Kuria E (2005) Hygienic and sanitary practices of vendors of Street food in Nairobi, Kenya. African Journal of Food Agriculture Nutrition and Development 5: 1.

23. Benny-Ollivierra C, Badrie N (2007) Hygienic practices by vendors of the street food "doubles" and public perception of vending practices in trinidad, west indies. Journal of Food Safety 27: 66-81.

24. Omemu AM, Aderoju ST (2008) Food safety knowledge and practices of street food vendors in the city of Abeokuta, Nigeria. Food control 19: 396402.

25. Gowri B, Vasantha KP, Sivakumar M (2011) Microbial Quality, Nutritional Knowledge and Food Hygienic Practices Among Street Food Vendors Non-journal. ERIC Number: ED527336.

26. Adjrah Y, Soncy K, Anani K, Blewussi K, Karou DS, et al. (2013) Socioeconomic profile of street food vendors and microbiological quality of readyto-eat salads in Lomé. International Food Research Journal 20: 65-70.

27. Liu Z, Zhang G, Zhang X (2014). Urban street foods in Shijiazhuang city, China: Current status, safety practices and risk mitigating strategies. Food Control 41: 212-218.

28. Burt BM, Volel C, Finkel M (2003) Safety of Vendor-Prepared Foods: Evaluation of 10 Processing Mobile Food Vendors in Manhattan. Public Health Reports 118: 470-476.

29. Moutz E, Suliman S, Abdalla M (2012) Surveillance of food safety practices of Street food- vendors in Gizan Saudi Arabia. Agriculture \& Forestry 58: 119-128.

30. Azanza MPV, Gatchalian CF, Ortega MP (2000) Food safety knowledge and practices of streetfoodvendors in a Philippines university campus. Int $\mathrm{J}$ Food Sci Nutr 51: 235-246.

31. Choudhury M, Mahanta L, Goswami J, Mazumder M, Pegoo B (2011a) Socio-economic profile and food safety knowledge and practice of street food vendors in the city of Guwahati, Assam, India. Food Control 22: 196 $-203$.

32. Lucca A, Ferraz da Silva Torres EA (2006) Street-food: The hygiene conditions of hot-dogs sold in Sao Paulo, Brazil. Food Control 17: 312-316. 
Citation: Sánchez MP, Lugo D, Millán R, Verdú A, Raposo A, et al. (2015) Mobile Artisanal Cheese Vending in Small Street Markets of Gran Canaria. Int J Clin Nutr Diet 1: 101. doi: http://dx.doi.org/10.15344/ijend/2015/101

33. Choudhury M, Mahanta L, Goswami J, Mazumder M (2011b) Will capacity building training interventions given to street food vendors give us safer food?: A cross-sectional study from India. Food Control 22: 1233-1239.

34. Sun YM, Wang, ST, Huang KW (2012) Hygiene knowledge and practices of night market food vendors in Tainan City, Taiwan. Food Control 23: 159164 .

35. da Silva SA, Vieira Cardoso RC, Wenceslau Goes JA, Nascimento Santos J, Pascoal Ramos F, et al. (2014) Street food on the coast of Salvador Bahia, Brazil: A study from the socioeconomic and food safety perspectives. Food Control 40: 78-84.

36. Lucan SC, Varona M, Maroko AR, Bumol J, Torrens L, et al. (2013) Assessing mobile food vendors (a.k.a. street food vendors) methods, challenges, and lessons learned for future food-environment research. Public Health 27: 766-776.

37. Pal Thakur C, Mehra R, Narula C, Mahapatra S, Kalita TJ (2013) Food safety and hygiene practices among street food vendors in Delhi, India. International Journal of Current Research $5:$ 3531-3534.

38. Okojie PW, Isah EC (2014) Sanitary Conditions of Food Vending Sites and Food Handling Practices of Street Food Vendors in Benin City, Nigeria: Implication for Food Hygiene and Safety. Journal of Environmental and Public Health: 701316. 